\title{
Species composition and abundance of the benthic community of Axiidea and Gebiidea (Crustacea: Decapoda) in the Marapanim Bay, Amazon estuary, northern Brazil
}

\author{
Dalila Costa Silva \& Jussara Moretto Martinelli-Lemos
}

Laboratório de Biologia Pesqueira e Manejo dos Recursos Aquáticos, Grupo de Pesquisa em Ecologia de Crustáceos da Amazônia, Instituto de Ciências Biológicas, Universidade Federal do Pará. Avenida Augusto Corrêa 1, 66075-110 Belém, PA, Brazil.E-mail: dalila@ufpa.br; jussara@ufpa.br

\begin{abstract}
The thalassinideans (Axiidea and Gebiidea) encompasses approximately 615 species with reclusive habits, generally confined to extensive galleries burrowed into the sand or mud and, more rarely, in openings in reefs or the cavities of sessile animals such as sponges and coral. These species use the galleries for shelter, feeding and breeding, except during the pelagic larval stage. They inhabit estuaries, bays, lagoons, beaches, seas and both tropical and temperate oceanic areas throughout the world, distributed predominantly in the intertidal zone (mid-littoral and infralittoral zones). The aim of the present study was to assess the species composition and abundance of thalassinideans, comparing two micro-habitats (consolidated and non-consolidated substrates), and determine whether there is a correlation between abundance of the organisms and time of the year, collection sites or salinity. Twelve monthly samplings were carried out between August 2006 and July 2007 over consolidated and non-consolidated bottoms of the upper and lower portions of the mid-littoral zones, with three sub-samplings, totaling 48 monthly samples and 576 in all. A total of 651 individuals were collected - 114 Lepidophthalmus siriboia Felder \& Rodrigues, 1993 and 537 Upogebia vasquezi Ngoc-Ho, 1989. There was correlation between the abundance of both species and salinity, but $U$. vasquezi was more abundant in the rainy season. Lepidophthalmus siriboia appears to prefer non-consolidated substrates, whereas $U$. vasquezi prefers consolidated substrates. The recruitment period for the callianassid $L$. siriboia appears to occur in just two periods of the year and is more intense in the dry season, whereas $U$. vasquezi is more frequent throughout the year. The smallest and largest sizes (carapace length $-\mathrm{CL}$ ) recorded for $L$. siriboia were smaller than those recorded for the species in northeastern region of Brazil. CL values for ovigerous females suggest that $U$. vasquezi reaches sexual maturity at a smaller size than L. siriboia.
\end{abstract}

KEY WORDS. Benthos; intertidal; thalassinideans.

Benthic coastal habitats are among the most productive marine environments on the planet. Consolidated substrates (rock formations, rocky beaches and pebbles) and non-consolidated substrates (sand and mud) are of considerable importance, as they house a large number species with considerable economic and ecological potential (Gomes et al. 2002, CoutinHO 2002). Benthic organisms are of considerable importance to the transformation and recycling of detritus, dissolved organic matter and nutrients from the water column deposited on the bottom. These organisms include microscopic forms (fungi and bacteria) and larger animals, such as crabs, shrimp and mollusks, as well as a large variety of plants.

Among the benthic decapod crustaceans, the infraorders Axiidea de Saint Laurent, 1979 and Gebiidea de Saint Laurent, 1979 encompasses approximately 615 species with reclusive habits, generally confined to extensive galleries burrowed in the sand or silt/clay and, more rarely, in openings of reefs or the cavities of sessile animals such as sponges and coral (RoDrigues \& Pezzuto 1999, De Grave et al. 2009). Crustaceans use the galleries for shelter, feeding and breeding, except during the pelagic larval stage (Griffs \& Chavez 1988). Thalassinideans inhabit estuaries, bays, lagoons, beaches, seas and both tropical and temperate oceanic areas throughout the world (Rodrigues \& PezzuTo 1999), distributed predominantly in the intertidal zone (midlittoral and infralittoral zones).

Commonly known by the names of "yabby", "ghost shrimp", "mud shrimp" (internationally) and "tamaru" or "corrupto" (Brazil), these crustaceans have been caught and used as bait for more than 20 years along oceanic beaches from the northeastern to southern coast of Brazil (SouzA \& Borzone 2003). There are as yet no records of this type of use of the species for northern Brazil. The capture of thalassinideans is carried out by amateur fishermen, who use a manual suction pump made up of a polyvinyl chloride (PVC) pipe equipped 
with an inner plunger that creates negative pressure when pulled over the openings in galleries on the sediment surface (Rodrigues \& Pezzuto 1999, Souza \& Borzone 2003).

The ecological role of thalassinideans has been identified above all by processes associated to their highly specialized way of life, which has led some researchers to compare their function in the marine environment with that performed by oligochaets in terrestrial soil (Rodrigues \& Pezzuto 1999), as they build extensive galleries, increasing the draining, aeration, mixture and churning of the sediment (RUPPERT et al. 2005). The galleries formed by the Axiidea and Gebiidea can undergo intense fossilization, making them extremely useful to the identification of old coastlines and thereby assisting in the interpretation of variations in sea level having occurred over geological time (Rodrigues \& Pezzuto 1999). Their use as bioindicators of water quality is equally recommended, as they reflect changes in the environment (Esteves 1998).

Thalassinidean species exercise considerable influence over the dynamics of coastal sediments and the structure of coastal benthic communities (BotTer-CarvalHo 2007). Through their burrowing and feeding mechanisms, these organisms cause the large-scale remobilization of the substrate (bioturbation) and the circulation of water in the interior of the galleries (Rodrigues \& Pezzuto 1999). They also enhance oxygenation and mineralization processes in the interior of the sediment and play an important role in the recycling of organic matter and nutrients imprisoned in the substrate by the process of sedimentation. However, with this churning of the sediment, thalassinideans may cause the remobilization and redistribution of pollutants such as radioactive elements and heavy metals (Botter-Carvalho 2007).

Fisheries targeting these burrowing organisms can cause changes in both this group as well as other species in the sediment due to the catching method employed. Excessive fishing efforts can lead to the overexploitation of the resource and even the complete disappearance of the target population (SouzA $\&$ Borzone 2003).

The occurrence of 43 species has been recorded for the Brazilian coastline (Melo 1999, Nucci \& Melo 2001), among which, ten occur on the coast of the state of Pará in northern Brazil: Neocallichirus grandimana Gibbes, 1850; Corallianassa longiventris Edwards, 1870; Cheramus marginatus Rathbun, 1901; U. brasiliensis Holthuis, 1956; Dawsonius latispina Dawson, 1967; Sergio guara Rodrigues, 1971; Marcusiaxius lemoscastroi Rodrigues \& Carvalho, 1972; Upogebia marina Coelho, 1973; U. acanthura Coelho, 1973 and Lepidophthalmus siriboia Felder \& Rodrigues, 1993. Specimens from scientific collections include only six species of thalassinideans in the state of Pará (Barros \& Pimentel 2001). In the Amazon region, only two researches about thalassinideans were performed, describing the abundance of larval and adults of L. siriboia and Upogebia vasquezi Ngoc-Ho, 1989 and the morphology of the early larval stages of $U$. vasquezi (Oliveira et al. 2012a, b). Although the exploitation of these organisms - whether through their commercialization as bait for species of fish, artisanal activities or sport - is as yet of low intensity, studies on these crustaceans are needed so that surveys can be made regarding their ecology and programs and policies may be drafted aimed at the conservation and appropriate management of these animals that inhabit the coast of the state of Pará.

The aim of the present study was to assess the species composition and abundance of thalassinidean crustaceans, comparing two micro-habitats (consolidated and non-consolidated substrates) of the Marapanim estuary and determining whether there is a correlation between abundance of the organisms and time of the year, collection sites or salinity.

\section{MATERIAL AND METHODS}

The coast of the state of Pará in northern Brazil is shaped by islands, bays and estuaries, in which a broad range of mangroves are found, corresponding to $20 \%$ of mangroves along the entire Brazilian coastline (Herz 1991). Estuary waters are among the most fertile natural waters in the world and often exhibit much more productivity than the adjacent ocean or freshwater river (VILLEE et al. 1984). The Marapanim estuary (Fig. 1), located on the coastline of the region locally known as the 'Salgado Paraense', has an open connection to the Atlantic Ocean. It is dominated by macro-tides and meso-tides, which allow the penetration of salt water for dozens of kilometers into the river, thereby enabling the coexistence of different ecosystems. This region is classified as an area of extreme priority for conservation and the management of the benefits of Brazilian biodiversity (Ministério do Meio Ambiente 2004).

For the capture of thalassinideans, twelve monthly samplings were carried out between August 2006 and July 2007 on both consolidated and non-consolidated bottoms in the intertidal zone. Four sites were studied (two on each bank of the Marapanim River), with two microhabitats (consolidated and non-consolidated substrate) in two areas that make up the upper and lower portions of the mid-littoral zone, with three samples, totaling 48 monthly samples [4 sites (A1 and A2 - left bank, B1 and B2 - right bank) x 2 micro-habitats (consolidated and non-consolidated substrate) $\mathrm{x} 2$ areas (upper and low midlittoral zone) x 3 sub-samples $\mathrm{x} 12$ months] and 576 samples in all.

A polyvinyl chloride (PVC) sampler $(0.5 \mathrm{~m}$ in length by $0.5 \mathrm{~m}$ in width) and PVC suction tube $(0.9 \mathrm{~m}$ in length, $0.05 \mathrm{~m}$ in diameter) were used in the demarcated area and for the acquisition of the samples of benthic macrofauna, respectively. The collection sites were chosen randomly during low tide, when these intertidal regions of consolidated and non-consolidated substrate were exposed. This type of sampling was executed in three different, equidistant areas, following the same horizontal line in relation to the margin of the estuary (Fig. 1). 

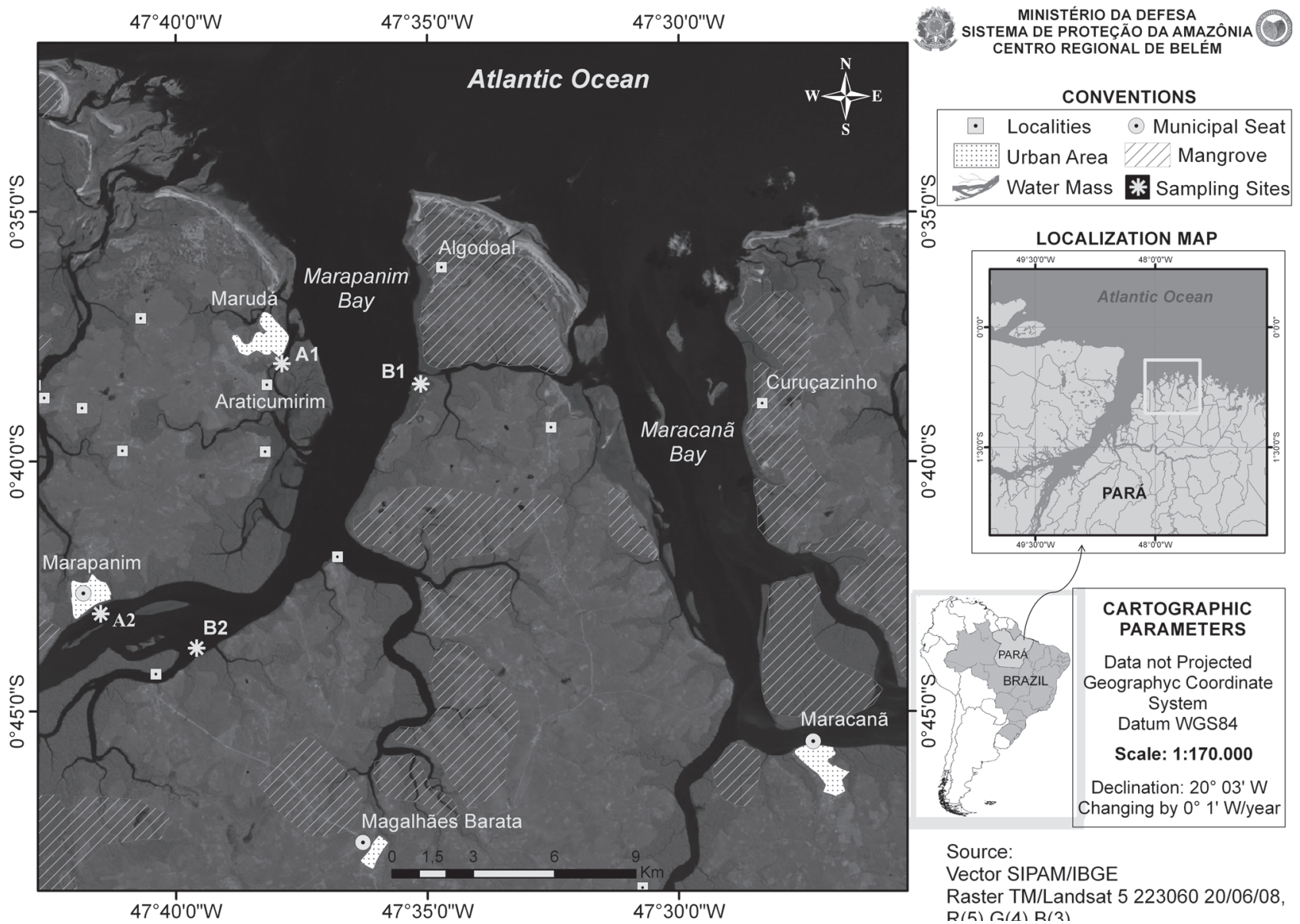

Figure 1. Geographical location of the study area, with indication of the four sampling site on the Marapanim River: A1 and A2 (left bank), B1 and B2 (right bank).

After removing rock fragments, the first five centimeters of consolidated substrate were collected in 3-mm mesh sieves and rinsed in running water from the estuary for the separation of the organisms. In the non-consolidated microhabitat, the number of galleries in each delimited areas was counted prior to the collection of the organisms for the subsequent density analysis. The sampled organisms were placed in labeled flasks, initially kept on ice and subsequently fixed in 70\% alcohol for transporting for analysis in the Laboratory of Fishery Biology and Management of Aquatic Resources - Universidade Federal do Pará. Aliquots of the water in the galleries were removed with the aid of a syringe $(3 \mathrm{~mL})$ for the determination of salinity using an optical refractometer. Data on total and mean monthly precipitation was obtained from the Agência Nacional de Águas (www.ana.gov.br).

In the laboratory, all material was identified to the species level using identification keys found in Melo (1999), Rodrigues \& Pezzuto (1999), Thatje (2000), Felder \& Staton (2000) and NGoc-Ho (2005). Specimens were weighed (total weight TW) using a scale with a precision of 0.01 grams and were measured for total length (TL) and carapace length (CL) using a caliper ruler with a precision of $0.01 \mathrm{~mm}$. Descriptive statistics on weight and length data by species was preformed in order to describe the composition of the sample. Species abundance was expressed in CPUA values - capture per unit of area $\left(\mathrm{m}^{2}\right):$ CPUA $=\mathrm{B} / \mathrm{A}$, in which $\mathrm{B}=$ weight in grams $\mathrm{A}=0.5$ of length $\times 0.5$ of width of the quadrant. Relative density was calculated by dividing the number of individuals by the area sampled.

The data were entered on spreadsheets and the corresponding analyses were performed with the aid of the BIOESTAT $5.0^{\circledR}$ (Ayres et al. 2007) and Statistica $7.0^{\circledR}$ (Statsoft 2004) programs. Non-parametric tests were used for data that did not exhibit normal distribution, even when submitted to logarithmic and square root transformations. The non-parametric Kruskal-Wallis test was used to test variations in salinity in re- 
lation to the seasons (dry and rainy), collection sites (A1, A2, B1 and B2) and type of substrate (consolidated and non-consolidated). The same test was use to determine the abundance of thalassindeans in relation to sampling month and abundance of $U$. vasquezi in relation to sampling site and type of substrate. As the data for L siriboia exhibited normal distribution, analysis of variance (ANOVA) was used to test the variation in abundance of this species regarding sampling site and type of substrate. Spearman's correlation analysis was used to determine correlations between salinity (dependent variable) and time of the year (independent variable) and also between salinity (independent variable) and density and CPUA of thalassinideans captured (dependent variables).

\section{RESULTS}

Monthly precipitation values in the Marapanim estuary region between August 2006 and July 2007 are displayed in Figure 2. Two distinct seasons were identified: a dry season (August to December 2006) and a rainy season (January to July 2007). Rainfall ranged from $10.4 \mathrm{~mm}$ in August 2006 to 760.6 $\mathrm{mm}$ in February 2007, totaling $2277.2 \mathrm{~mm}$ throughout the study period.

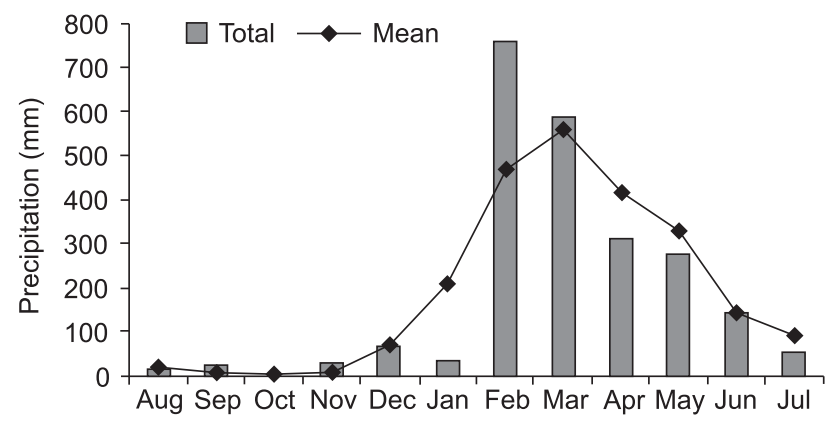

Figure 2. Total precipitation between August 2006 and July 2007 and mean annual precipitation of previous five years for the Marapanim estuary. Source: Agência Nacional de Águas (www.ana.gov.br).

The lowest salinity values recorded occurred during the rainy season. Minimum salinity of zero occurred in March 2007 (consolidated substrate/upper and lower region/site A2) and maximum salinity of 44 occurred in October 2006 (consolidated substrate; lower region/site A1). Mean salinity was 24.59 \pm 9.62 (standard deviation) in the dry season and $13.25 \pm 6.06$ in the rainy season. Significant differences in salinity were found in relation to the sampling sites $\mathrm{A} 1, \mathrm{~A} 2, \mathrm{~B} 1$ and $\mathrm{B} 2 \mathrm{(H}=107.35$, $\mathrm{p}<0.05)$ and between the dry and rainy seasons $(\mathrm{H}=164.37$, $\mathrm{p}$ $<0.05)$. No significant differences in salinity were observed regarding the type of substrate (consolidated and non-consoli- dated) or with regard to the sampling area (upper and lower mid-littoral zone). Fluctuations in the salinity of the water in the galleries in relation to substrate, area, site and sampling month are illustrated in Figures 3-18.

A total of 651 individuals were collected, 114 L. siriboia and 537 U. vasquezi. Statistically significant differences were found between the number of individuals and species collected: $U$. vasquezi was denser $(\mathrm{H}=18.51, \mathrm{p}<0.05)$; sampling sites $\mathrm{A} 1$ and $\mathrm{B} 2$ were those of the highest occurrence $(\mathrm{H}=51.20, \mathrm{p}<$ $0.05)$; in non-consolidated substrate $(\mathrm{H}=18.58, \mathrm{p}<0.05)$ and greater occurrences of thalassinideans were observed in the months of April and June $(H=20.27, \mathrm{p}<0.05)$. Between the two species, $L$. siriboia was more frequent at site A1 and did not occur at site A2, whereas $U$. vasquezi occurred in all four sites, with $\mathrm{B} 2$ and $\mathrm{B} 1$ as the sites of highest and lowest occurrence, respectively (Figs 19 and 20). Figures 21 and 22 displays the number of $L$. siriboia and $U$. vasquezi specimens in relation to sampling month. The former species occurred in its lowest number in March 2007 ( $\mathrm{n}=3$ ) and highest number in June 2007 ( $\mathrm{n}=31$ ). The latter species did not occur in August 2006 and its highest occurrence was in March 2007 ( $n=95)$.

Descriptive statistics for the measurement of carapace length (CL) for the two thalassinidean species are displayed in Table I.

The frequency distribution of carapace length for $L$. siriboia is displayed in Figure 23. At site A1, there was unimodal distribution, with a mode in class seven (7 to $7.99 \mathrm{~mm}$ ). At site B1, there was bimodal distribution, with the highest number of individuals in class six (6 to $6.99 \mathrm{~mm}$ ), followed by class two (2 to $2.99 \mathrm{~mm}$ ). Upogebia vasquezi had a greater number of individuals in classes four (4 to $4.99 \mathrm{~mm}$ ) and three (3 to 3.99 $\mathrm{mm})$ at sites A1 and B1, respectively. There was a mode in class nine ( 9 to $9.99 \mathrm{~mm}$ ) at site $\mathrm{A} 2$ and in class five (5 to $5.99 \mathrm{~mm}$ ) at site B2 (Fig. 24). The frequency distribution of the CL of the thalassinideans in relation to sampling area (upper and lower mid-littoral zone) reveals that $L$. siriboia occurred more in the lower portion, with a mode in class seven $(7.00$ and $7.99 \mathrm{~mm})$, whereas $U$. vasquezi had its highest frequency in class five (5.00 to $5.99 \mathrm{~mm}$ ) in the upper portion of the mid-littoral zone (Figs 25 and 26). The frequency distribution of carapace length classes (CL) for L. siriboia in relation to sampling months is displayed in Figure 27. The main modes occurred in September in class seven $(7.00$ to $7.99 \mathrm{~mm})$ as well as November and March in class eight ( 8.00 to $8.99 \mathrm{~mm}$ ). There were no records of juveniles from October to December and from March to May. For $U$. vasquezi, the highest CL modes occurred in September (Class Seven -7.00 to $7.99 \mathrm{~mm}$ ) and November (class ten -10.00 to $10.99 \mathrm{~mm}$ ). Beginning in February, there was a uniform occurrence of individuals from the smallest to largest classes and the entrance of juveniles was recorded in most months. There were no records of this species in the month of August (Fig. 28).

The abundance of thalassinideans in relation to sampling sites and areas is illustrated in Figures 29-32. For both L. siriboia 

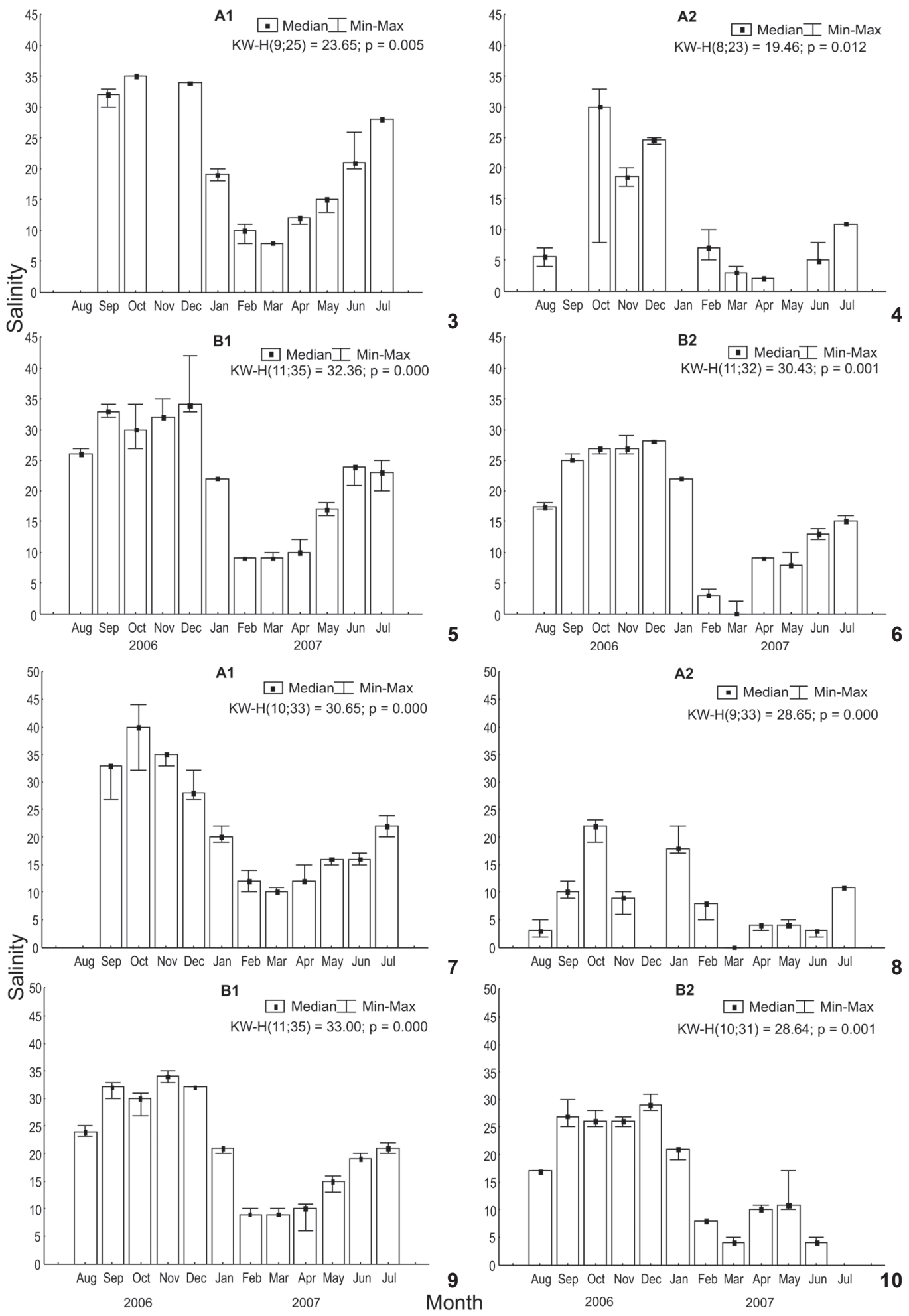

Figures 3-10. Salinity of water collected throughout the sampling period at the four sampling sites with consolidated substrate in the (36) upper and (7-10) lower portions of the mid-littoral zone in the Marapanim estuary, Pará, Brazil. 

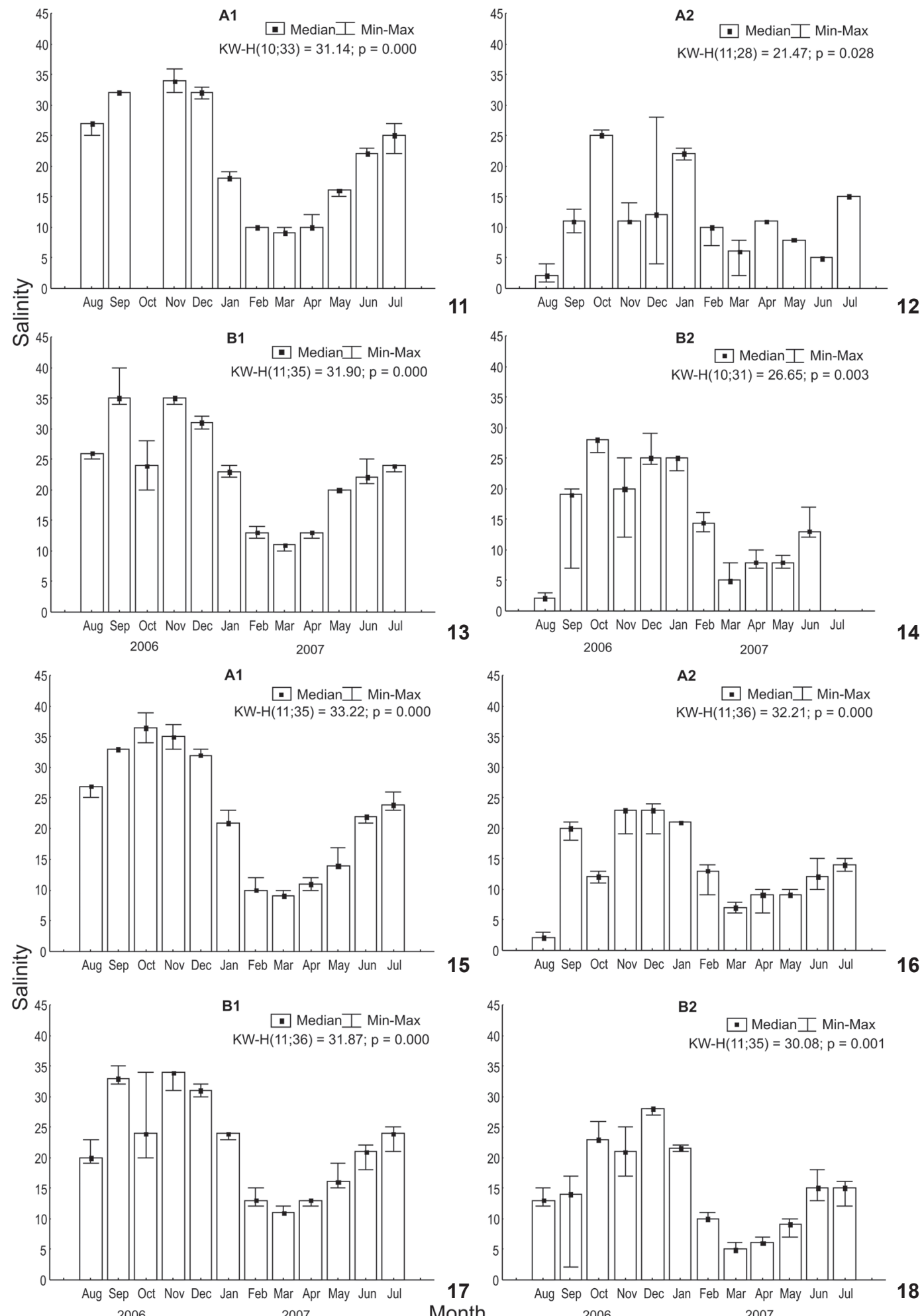

Figures 11-18. Salinity of water collected throughout the sampling period at the four sampling sites with non-consolidated substrate in the (11-14) upper and (15-18) lower portions of the mid-littoral zone in the Marapanim estuary, Pará, Brazil. 
Table I. Descriptive statistics of carapace length (mm) of 68 Axiidean and Gebiidea species collected between August 2006 to July 2007 in the Marapanim estuary, Pará, Brazil. (F) Female, (OF) ovigerous female, (M) male, (UND) undetermined sex.

\begin{tabular}{llcccc}
\hline \multicolumn{1}{c}{ Species } & \multicolumn{1}{c}{ Sex } & Minimum & Maximum & Mean & Standard deviation \\
\hline \multirow{4}{*}{ Lepidophthalmus siriboia } & Female & 2.78 & 9.35 & 6.58 & 1.77 \\
& Ovigerous female & 7.01 & 9.20 & 8.03 & 0.75 \\
& Undetermined sex & 1.15 & 7.97 & 3.42 & 2.16 \\
& Male & 3.94 & 9.64 & 6.91 & 1.20 \\
\hline Total & & 1.15 & 9.64 & 6.34 & 2.07 \\
\hline \multirow{3}{*}{ Upogebia vasquezi } & Female & 2.80 & 12.98 & 6.62 & 2.18 \\
& Ovigerous female & 4.42 & 12.87 & 7.89 & 2.27 \\
& Undetermined sex & 2.17 & 8.50 & 4.67 & 1.99 \\
\hline Total & Male & 2.47 & 11.15 & 5.50 & 1.84 \\
\hline
\end{tabular}
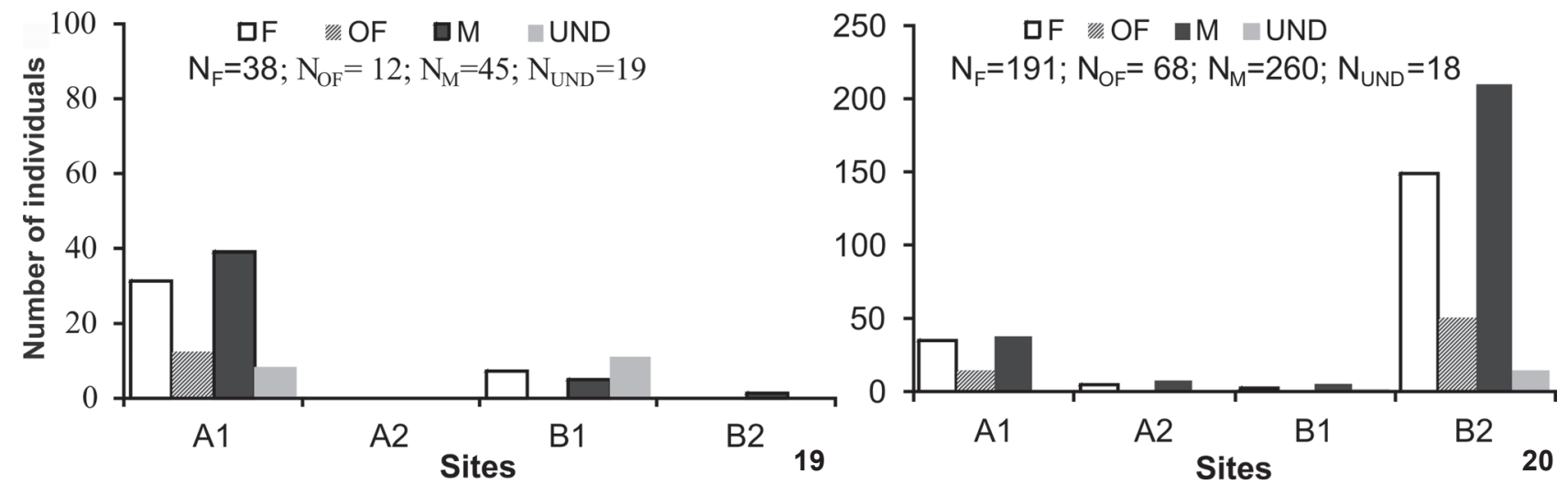

Figures 19-20. Number of L. siriboia and $U$. vasquezi individuals sorted by sex, according to species and sampling site from August 2006 to July 2007 in the Marapanim estuary, Pará, Brazil. (F) Female, (OF) ovigerous female, (M) male, (UND) undetermined sex.
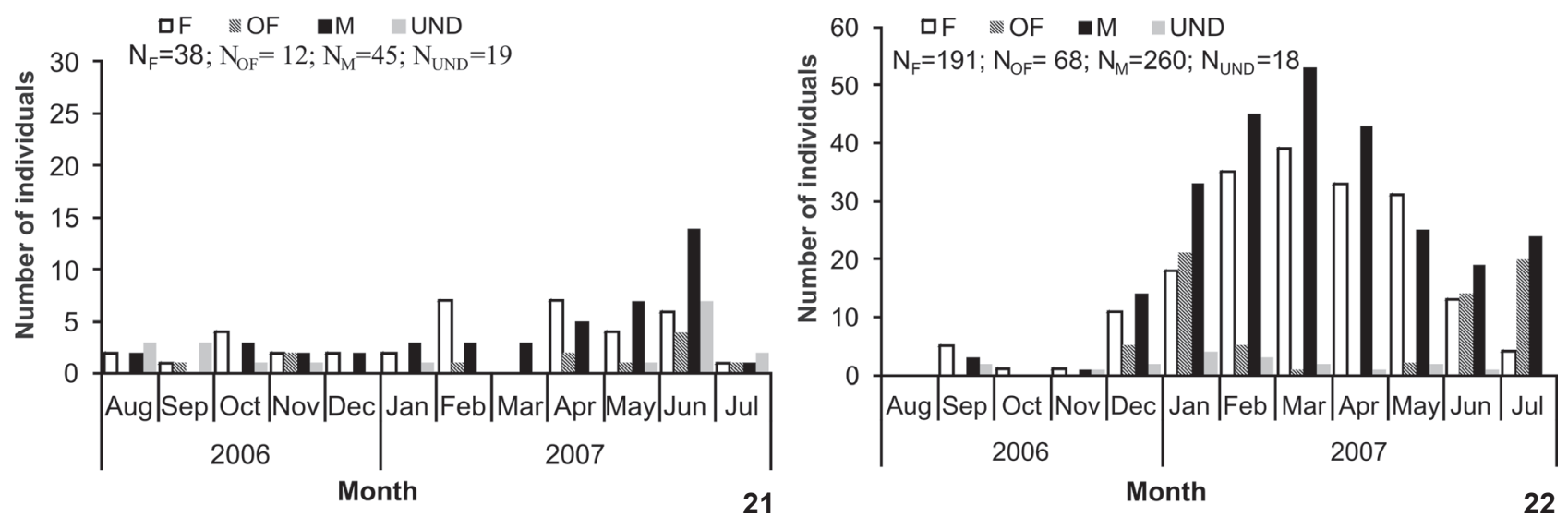

Figures 21-22. Number of L. siriboia and U. vasquezi individuals sorted by sex, according to the period from August 2006 to July 2007 in the Marapanim estuary, Pará, Brazil. (F) Female, (OF) ovigerous female, (M) male, (UND) undetermined sex. 

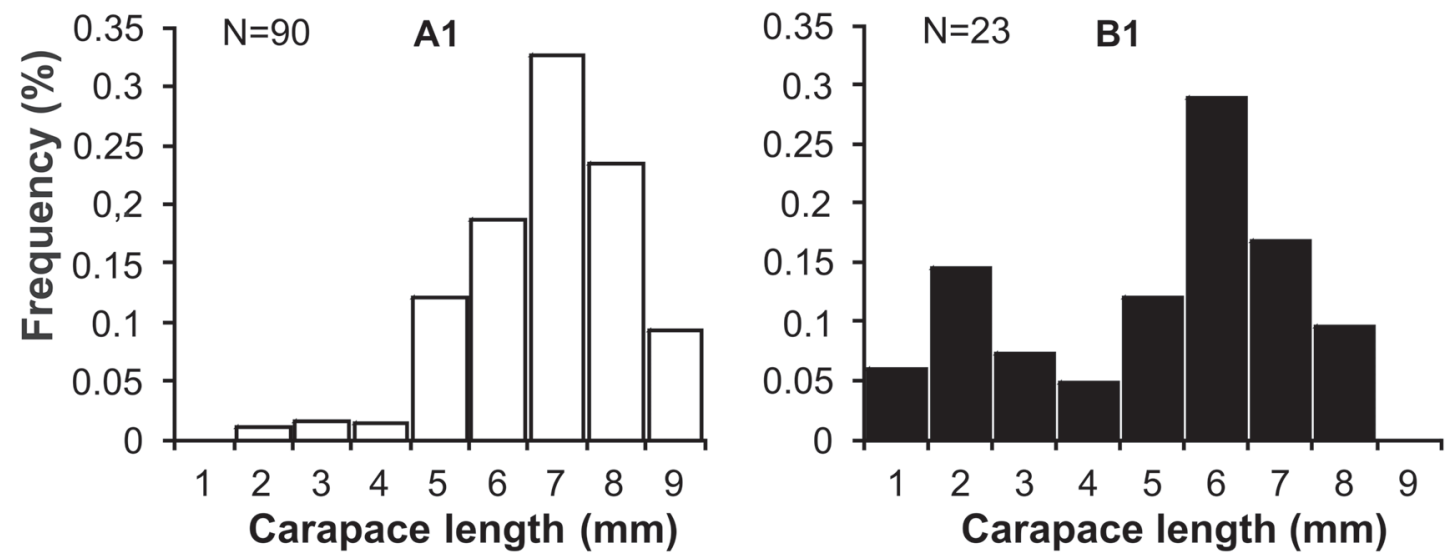

Figure 23. Frequency distribution of carapace length (CL) of L. siriboia collected as sites A1 and B1 from August 2006 to July 2007 in the Marapanim estuary, Pará, Brazil.
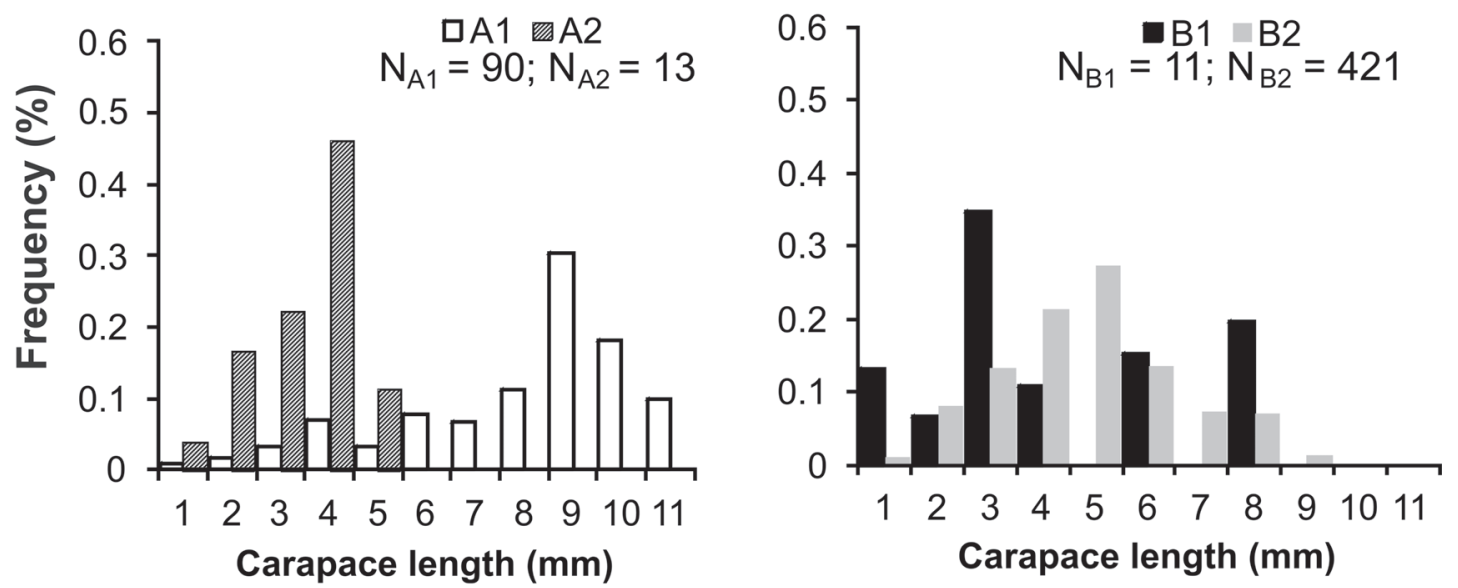

Figure 24. Frequency distribution of carapace length (CL) of $U$. vasquezi collected as sites A1, A2, B1 and B2 from August 2006 to July 2007 in the Marapanim estuary, Pará, Brazil.
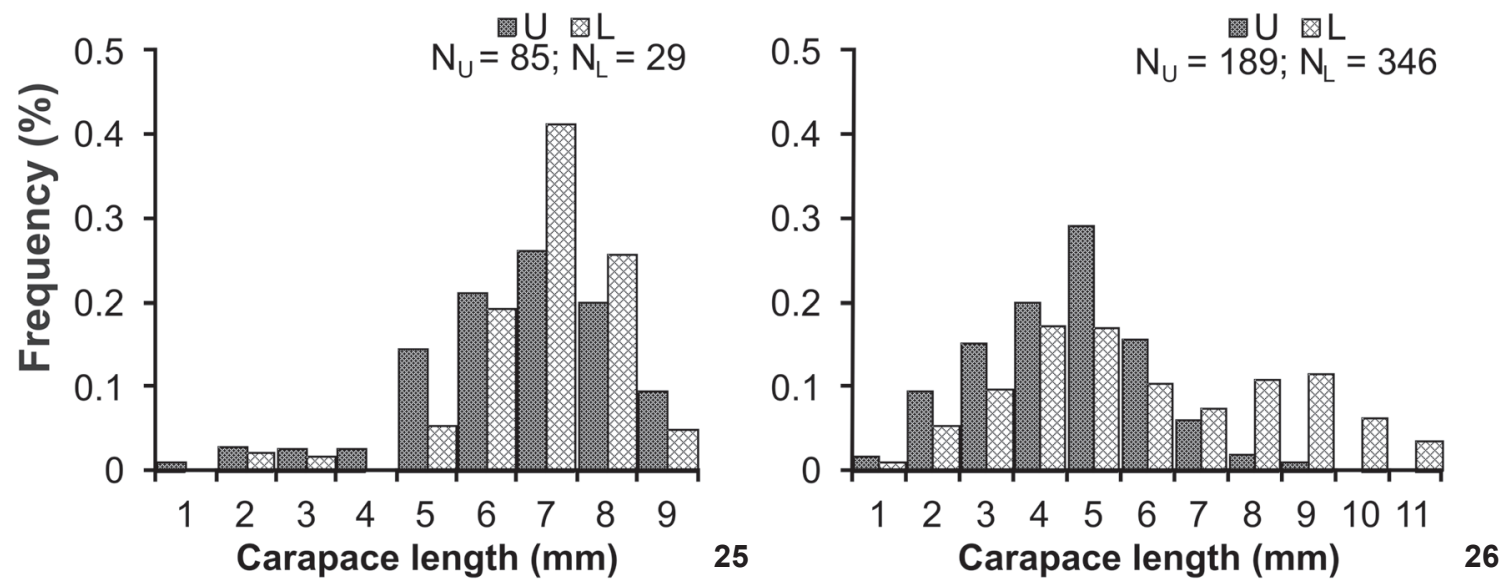

Figures 25-26. Frequency distribution of carapace length (CL) of (25) L. siriboia and (26) $U$. vasquezi collected in the upper (U) and lower (L) portions of the mid-littoral zone from August 2006 to July 2007 in the Marapanim estuary, Pará, Brazil. 

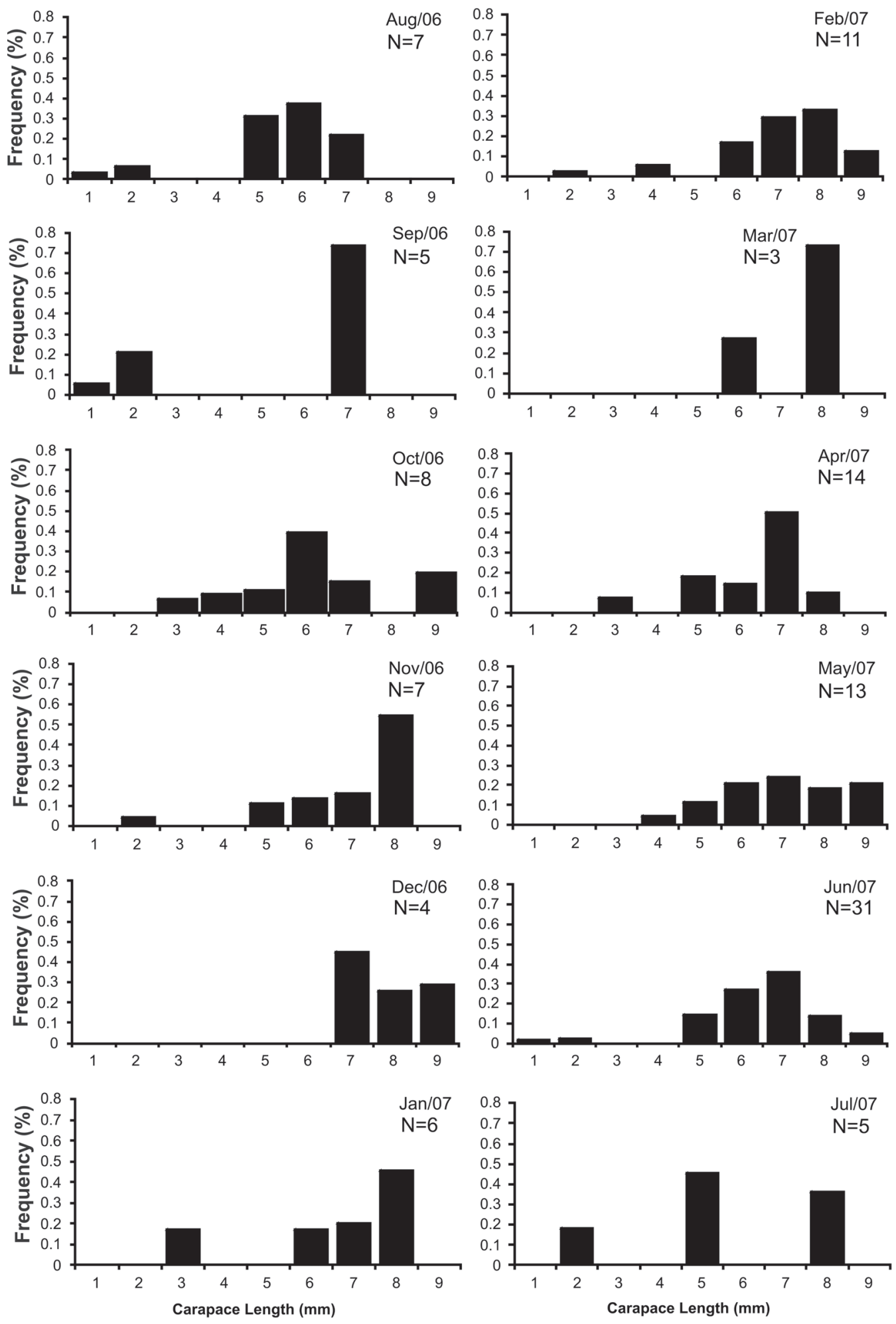

Figure 27. Frequency distribution of carapace length (CL) classes of L. siriboia collected from August 2006 to July 2007 in the Marapanim estuary, Pará, Brazil. 

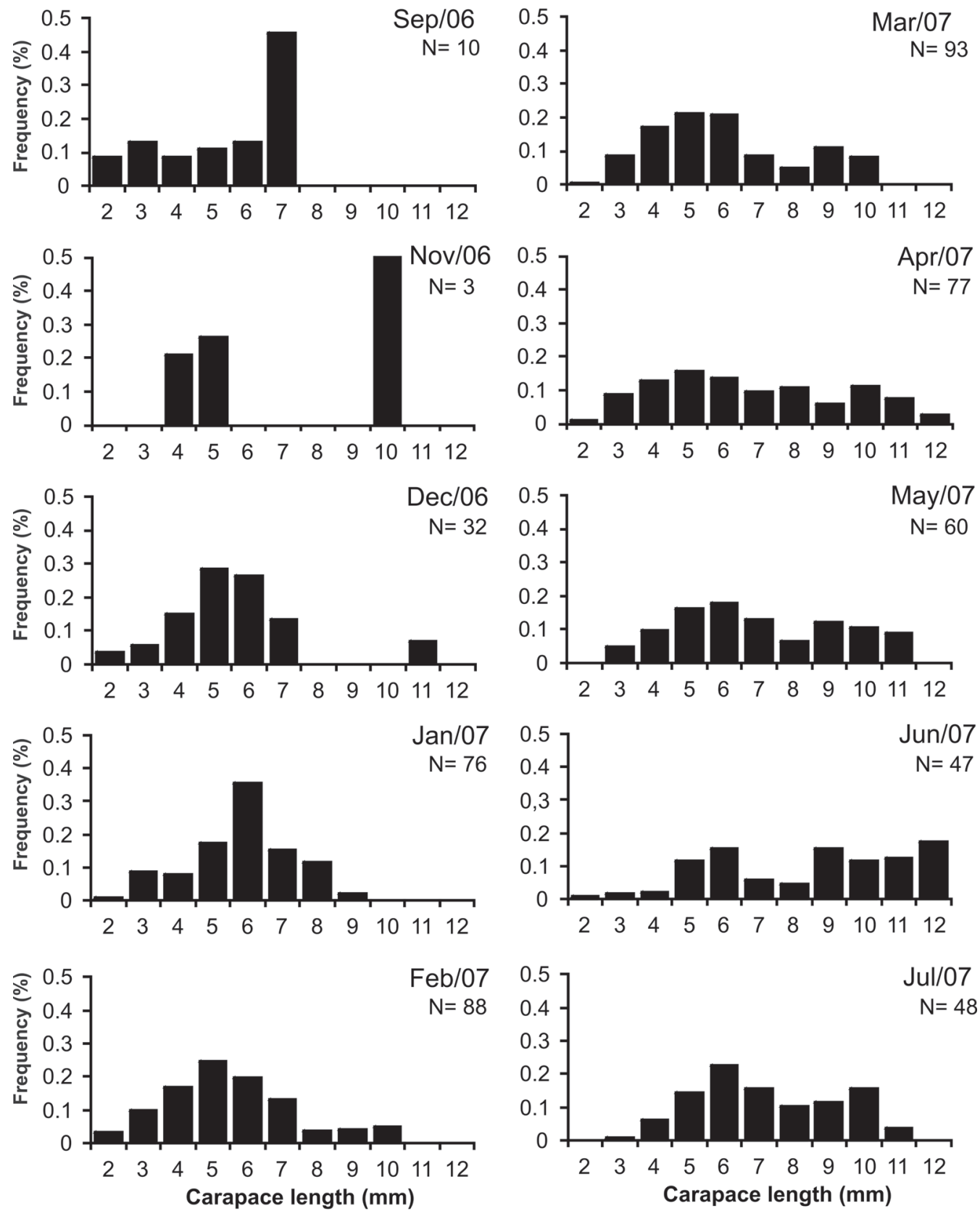

Figure 28. Frequency distribution of carapace length (CL) classes of U. vasquezi collected from August 2006 to July 2007 in the Marapanim estuary, Pará, Brazil.

and $U$. vasquezi, there were significant differences in relation to density (individuals $/ \mathrm{m}^{2}$ ) and CPUA $\left(\mathrm{g} / \mathrm{m}^{2}\right)$. L. siriboia exhibited the highest density and CPUA in the upper portion of site A1 (A1-u), whereas $U$. vasquezi exhibited its highest density in the lower portion of site B2 (B2-1) and highest CPUA in the lower portion of site A1 (A1-1). Analyzing the abundance of the thalassinideans in relation to site (Figs 33-36), L. siriboia had a greater abundance (density and CPUA) at site A1, whereas $U$. vasquezi had a greater abundance at site B2 (density) and site A1 (CPUA). In relation to substrate, L. siriboia was more abundant in terms of both density and CPUA in non-consolidated substrate, whereas $U$. vasquezi was more abundant in consolidated substrate. However, there were no statistically significant differences in L. siriboia abundance with regard to 

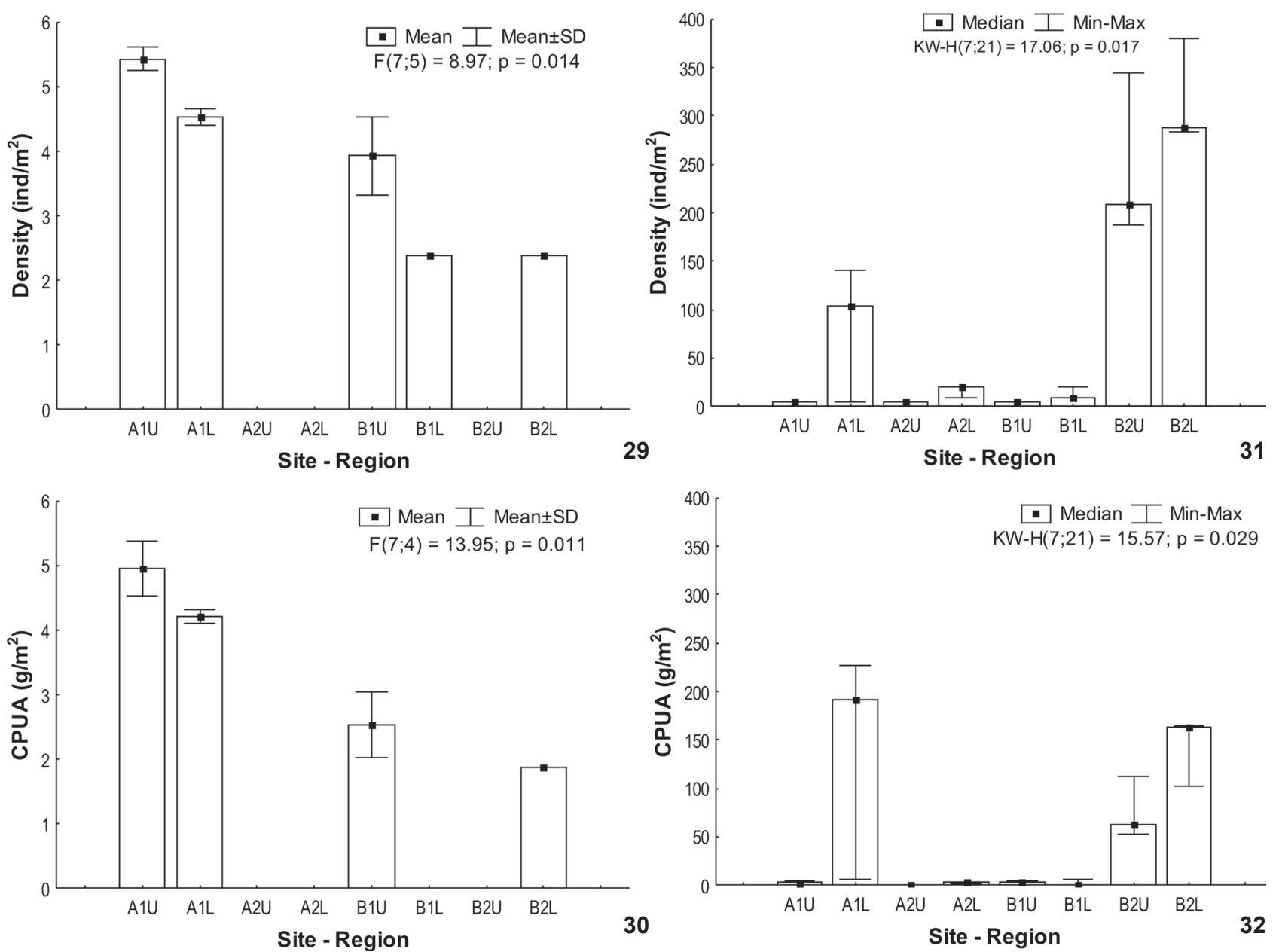

Figures 29-32. Density (individuals $\left./ \mathrm{m}^{2}\right)$ and CPUA $\left(\mathrm{g} / 35 \mathrm{~m}^{2}\right)$ of (29-30) L. siriboia and (31-32) U. vasquezi according to sampling sites and areas sampled from August 2006 to July 2007 in the Marapanim estuary, Pará, Brazil; A1, A2, B1 and B2 - sampling sites; U and L - upper and lower portions of the mid-littoral zone.

sites and type of substrate, whereas $U$. vasquezi exhibited significant differences for both variables (density and CPUA).

The abundance of thalassinideans in relation to time of the year is illustrated in Figures 37-40. The highest mean density and CPUA values for $L$. siriboia were $62 \mathrm{ind} . / \mathrm{m}^{2}$ and $42.52 \mathrm{~g} /$ $\mathrm{m}^{2}$, respectively, during the months of June and May. The lowest density was 6 ind. $/ \mathrm{m}^{2}$ in March and lowest CPUA was $3.54 \mathrm{~g} /$ $\mathrm{m}^{2}$ in July. However, no statistically significant differences in abundance were found between sampling months. For $U$. vasquezi, the highest mean density $\left(95 \mathrm{ind} . / \mathrm{m}^{2}\right)$ and CPUA (148.4 $\left.\mathrm{g} / \mathrm{m}^{2}\right)$ values occurred in June and the lowest mean density (4 ind. $\left./ \mathrm{m}^{2}\right)$ and CPUA $\left(0.44 \mathrm{~g} / \mathrm{m}^{2}\right)$ values occurred in October, with no record of the species in August. There were also no statistically significant differences in abundance (density and CPUA) found between sampling months for this species. The result of Spearman's correlation for $L$. siriboia density indicated that the species was positively correlated with CPUA $(\mathrm{R}=0.66, \mathrm{p}<0.05)$ and there was a positive correlation between salinity and season (dry and rainy) $(\mathrm{R}=0.70, \mathrm{p}<0.05)$. L. siriboia demonstrated no correlations regarding density or CPUA with salinity. The density and CPUA of $U$. vasquezi were negatively correlated with season $(\mathrm{R}=-0.65, \mathrm{p}<0.05$ and $\mathrm{R}=-0.83, \mathrm{p}<0.05)$, respectively, but there were no correlations between these variables and salinity. However, there was a positive correlation between salinity and season (dry and rainy) $(\mathrm{R}=0.70, \mathrm{p}<0.05)$.

\section{DISCUSSION}

Approximately $50 \%$ of the total area of the state of Pará, encompassing the southern and southeastern portions as well as part of the northern and northeastern portions of the state, has annual precipitation values between 1900 and $2400 \mathrm{~mm}$ 

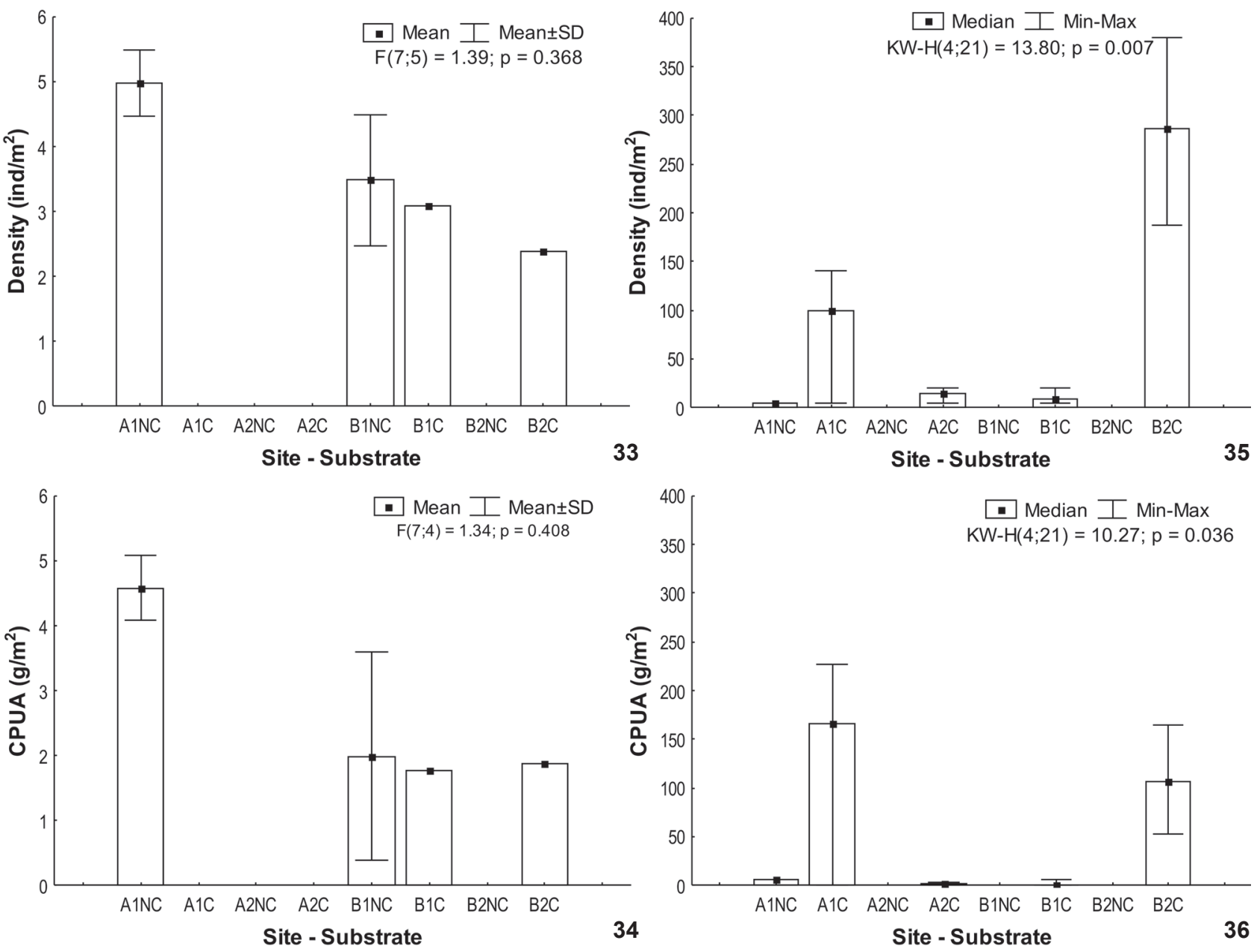

Figures 33-36. Density (individuals $\left./ \mathrm{m}^{2}\right)$ and CPUA $\left(\mathrm{g} / \mathrm{m}^{2}\right)$ of (33-34 L. siriboia and (35-36) U. vasquezi according to sampling sites and type of substrate in the period from August 2006 to July 2007 in the Marapanim estuary, Pará, Brazil; A1, A2, B1 and B2 - sampling sites; $\mathrm{C}$ and NC - consolidated and non-consolidated substrate.

(MORAEs et al. 2005). The Marapanim region during the year of the present study had a precipitation value of $2277.2 \mathrm{~mm}$, which is within this range and is characteristic of tropical regions.

The salinity of the water in the galleries ranged from 0 to 44 in the rainy and dry seasons, respectively, with the lowest values in February and March 2007 resulting from the intensification of rainfall in this period, which contributed to the increase in outflow from the Marapanim River in the estuary. This pattern has also been observed in other estuaries in the state of Pará, such as the Caeté estuary, the river of which drains $3000 \mathrm{~km}^{2}$ of indirect channels from the mangroves (L. Schwendenmann, unpubl. data) and its outflow ranges from 0.3 to $180 \mathrm{~m}^{3} / \mathrm{s}$ in the dry and rainy seasons, respectively (LARA 2003). Salinity appears to be the most important factor, acting as a regulating mechanism for the distribution and abundance of macro-crustaceans in the estuary complex (TeIXeIrA 1998).
However, this factor did not have a significant influence over the abundance of organisms in the Marapanim estuary. Although the number of $L$. siriboia in the period with the most intense rain (March 2007) was low, this number was not statistically different from the other months. Perhaps water and air temperature is the variable that most influences the life of the species, as observed by BOtTER-CARvalHo (2007) in a study on Callichirus major (Say, 1818) (Callianassidae) in the state of Pernambuco in northeastern Brazil and by Posey (1986) in a study on Callianassa californiensis Dana, 1854 in the United States, who found lower densities during the winter, suggesting that this finding may be associated to water and air temperature, as thalassinideans are cold-blooded animals.

Substrate appears to be fundamental to the structuring of species in the Marapanim estuary. Lepidophtalmus siriboia seems to have preference for sandy sediment, as the highest 


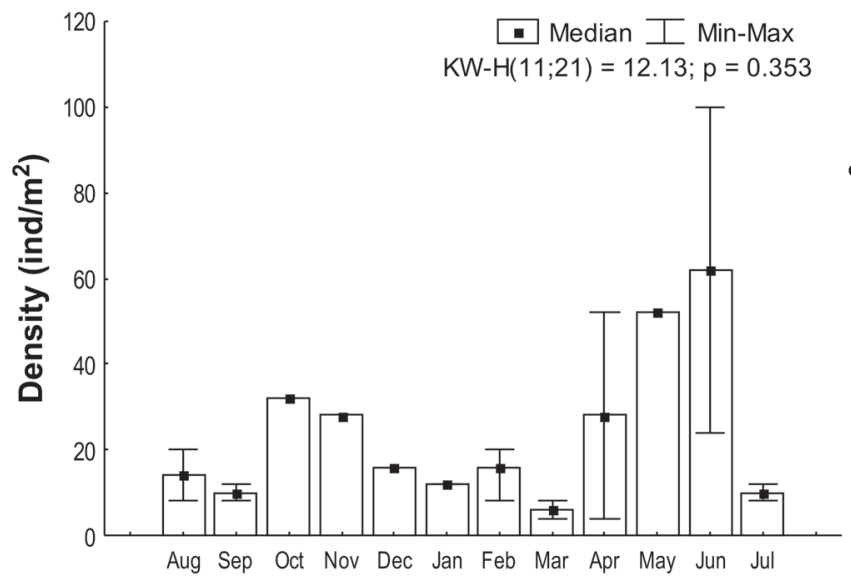

Month

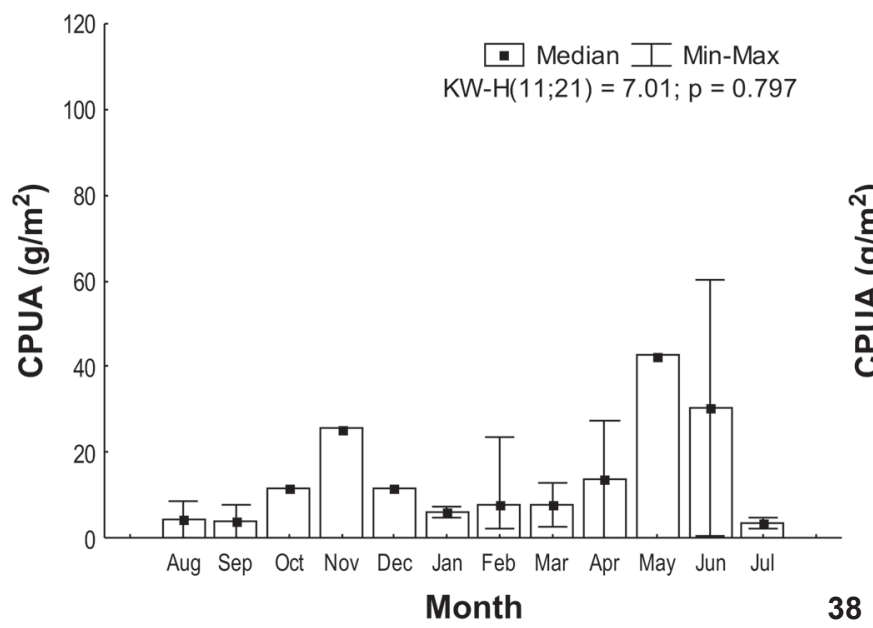

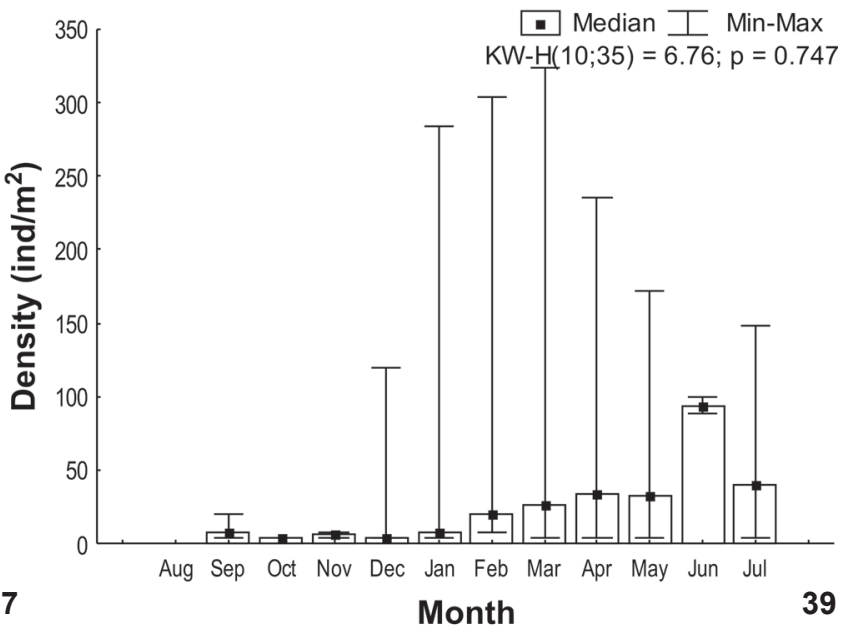

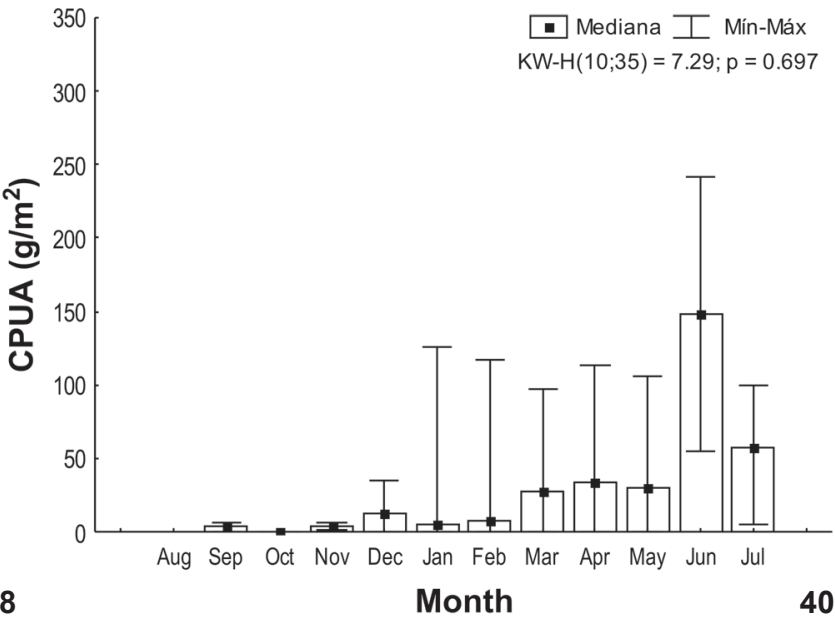

Figures 37-40. Density (individuals $\left./ \mathrm{m}^{2}\right)$ and CPUA $\left(\mathrm{g} / \mathrm{m}^{2}\right)$ of (37-38) L. siriboia and (39-40) U. vasquezi according to sampling months in the period from August 2006 to July 2007 in the Marapanim estuary, Pará, Brazil.

density occurred in the non-consolidated substrate at site A1, where both adults and juveniles were found. Therefore, the type of sediment could act as a limiting factor for this species, which explains the greater concentration of this crustacean in the lower portion of mid-littoral zone, which is a region that is less subject to desiccation. Studies on C. major have found that this species has a preference for sediments with very fine, well selected sand (Souza \& Borzone 2003, Botter-Carvalho 2007).

In a study on the biology of Upogebia paraffinis Williams, 1993 and the new occurrence of the species in the state of Paraná in southern Brazil, Melo et al. (2004) found that the species demonstrated a preference for dark sandy-muddy material stemming from the decomposition of vegetal matter from nearby mangroves. This could also be applied to $U$. vasquezi, as this species exhibited greater density at site B2, which is in the innermost portion of the Marapanim estuary, with the largest extensions of mangroves, and is the most preserved in comparison to the other sampling sites. Despite being an environment with a consolidated substrate, B2 exhibited differences in relation to other sites with consolidated substrate. The rocks at this site have a more clay formation and are easily fragmented. When removed for the collection of the organisms, the material below them had a sandy-muddy aspect, which facilitates the life of these organisms in this environment, allowing their locomotion and the building of galleries as well as offering shelter for protection. Hence, this factor seems to be a favorable condition to the presence of $U$. vasquezi. The greater occurrence of $U$. vasquezi in consolidated substrates may explain the fact that they were found with greater frequency in the lower portion of the mid-littoral zone, as this area undergoes less impact from desiccation. The muddy material below the rock fragments remains moist, thereby providing favorable survival conditions for the species as well as other benthic organisms, as this area spends the least amount of time exposed during low tide. 
The non-occurrence of individuals from either species at site A2 may be related to the fact that this site is under a strong anthropogenic influence, as it is located in front of the city of Marapanim, the sewage of which is untreated. During the samplings, large amounts of waste were observed as well as a very strong odor of sewage. These factors likely contributed toward the non-occurrence of the organisms, as they are also bioindicators of pollution.

Comparing the range of size variation in $L$. siriboia with the results of the study by BOTTER-CARVALHo (2007), the individuals in the Marapanim are smaller than those found in the state of Pernambuco (northeastern Brazil). The size frequency distribution of $L$. siriboia in relation to the months of the year suggests that there are two recruitment periods for the species, with the most intensive entrance of juveniles $(\mathrm{CL}<6 \mathrm{~mm})$ in August/September and the least intensive in April. A more intensive recruitment of juveniles in the dry season has also been described in study carried out by SouzA \& Borzone (2003), who suggest that the recruitment period of Callianassidae occurs in summer.

Frequency distribution data on $U$. vasquezi in relation to the sampling months indicate that this species reproduces more frequently throughout the year in comparison to $L$. siriboia, as the occurrence of juveniles in the population was found in all but three months. The abundance of $U$. vasquezi was greater in the rainy period (June 2007) and abundance exhibited a significant association to season of the year. The larvae of this species occurs in greater abundance in the dry season, indicating that the adults can be more euryhaline than the larvae (Oliveira et al. 2012a). The presence of thalassinideans in all age classes as well as the occurrence of ovigerous females at particular times of the year indicate that the Marapanim estuary is favorable to the development of these species.

Future studies determining the granulometry and organic matter content in the substrate will be carried out in order to complement the results obtained in the present study.

\section{ACKNOWLEDGMENTS}

The authors are grateful to the CT-Amazônia project 32/2005 BIODECA/CNPq (Process 553106/2005-8) for funding; to the Brazilian environmental agency IBAMA for granting the licenses for the collection of the organisms; to the Brazilian sponsoring agency CNPq for the PIBIC Scientific Initiation grant in the periods from August 2005 to July 2006 and August 2006 to July 2007; to Sistema de Proteção da Amazônia - SIPAM for the map of the study area; to the Universidade Federal do Pará through the Laboratory of Fishery Biology and Management of Aquatic Resources for its infrastructure that allowed the study to be carried out; to all the colleagues who helped in this study specially Daniely B. de Oliveira; and to Richard Boike for the English version.

\section{LITERATURE CITED}

Ayres, M.; M. Ayres Jr; D.L. Ayres \& A.S. Santos. 2007. BioEstat 5.0. Aplicações estatísticas nas áreas das ciências biomédicas. Belém, Sociedade Civil Mamirauá, 364p.

Barros, M.P. \& F.R. Pimentel. 2001. A fauna de Decapoda (Crustacea) do Estado do Pará,Brasil: lista preliminar de espécies. Boletim do Museu Paraense Emilio Goeldi, série Zoologia 17 (1): 1541.

BotTer-Carvalho, M.L. 2007. Population dynamics of Callichirus major (Say, 1818) (Crustacea, Thalassinidea) on a beach in northeastern Brazil. Estuarine, Coastal and Shelf Science 71 (3-4): 508-516. doi:10.1016/j.ecss.2006.09.001.

CoutinHo, R. 2002. Bentos de costões rochosos, p. 147-157. In: R.C. Pereira \& A. Soares-Gomes (Eds). Biologia marinha. Rio de Janeiro, Interciência, 382p.

De Grave S.; N.D. Pentcheff; S.T. Ahyong; T.Y. Chan; K.A. Crandall; P.C. Dworschak; D.L. Felder; R.M. Feldmann; C.H.J.M. Fransen; L.Y.D. Goulding; R. Lemaitre; M.E.Y. Low; J.W. Martin; P.K.L. NG; C.E. Schweitzer; S.H. Tan; D. Tshudy \& R. Wetzer. 2009. A classification of living and fossil genera of decapod crustaceans. Raffles Bulletin of Zoology 21, 1-109.

Esteves, F.A. 1998. Fundamentos de Limnologia. Rio de Janeiro, Interciência, 602p.

Felder, D.L. \& J.L. Staton. 2000. Lepidophthalmus manningi, a new ghost shrimp from the southwestern Gulf of Mexico (Decapoda: Thalassinidea Callianassidae). Journal of Crustacean Biology 20 (2): 170-181.

Gomes, A.S.; P.C. Paiva \& P.Y.G. Sumida. 2002. Bentos de sedimentos não-consolidados, p. 127-146. In: R.C. Pereira \& A. Soares-Gomes (Eds). Biologia marinha. Rio de Janeiro, Interciência, 382p.

GrIFFIs, R.B. \& F.L. ChavEz. 1988. Effects of sediment type on burrows of Callianassa californiensis Dana and C. gigas Dana. Journal of Experimental Marine Biology and Ecology 117 (3): 239253. doi: 10.1016/0022-0981(88)90060-3.

Herz, R. 1991. Manguezais do Brasil. São Paulo, Universidade de São Paulo, 54p.

LARA, R.J. 2003. Amazonian mangroves - A multidisciplinary case study in Pará State, North Brazil: Introduction. Wetlands Ecology and Management 11 (4): 217-221. doi: 10.1023/A:10250 12914237.

Melo, G.A.S. 1999. Manual de Identificação dos Crustáceos Decapoda do Litoral Brasileiro: Anomura, Thalassinidea, Palinuridea e Astacidea. São Paulo, Plêiade/FAPESP, 551p.

Melo, S.G.; J. DE Loyola-e-Silva \& A.L. Brossi-Garcia. 2004. Upogebia paraffinis Williams (Decapoda, Upogebiidae): biologia e nova ocorrência para o litoral do Estado do Paraná (Brasil). Acta Biológica Paranaense 33: 13-20.

Ministério do Meio Ambiente. 2004. Mapa das Áreas Prioritárias para a conservação dos biomas brasileiros. Pará. Available online at: http://www.mma.gov.br/?id_estrutura = 14\&id_conteudo = 743. [Acessed: 01/XII/2007]. 
Moraes, B.C.; J.M.N. Costa; A.C.L. Costa \& M.H. Costa. 2005. Variação espacial e temporal da precipitação no estado do Pará. Acta Amazonica 35 (2): 207-214.

NGoc-Ho, N. 2005. Thalassinidea (Crustacea, Decapoda) from French Polynesia. Zoosystema 27 (1): 47-83.

NucCI, P.R. \& G.A.S. MeLo. 2001. First record of Upogebia inomissa Williams, 1993 (Decapoda, Thalassinidea, Upogebiidea) in Brazil. Nauplius 9: 71-71.

Oliveira, D.B.; J.M. Martinelli \& F.A. Abrunhosa. 2012a. Density of larval and adult forms of the burrowing crustaceans Lepidophthalmus siriboia (Callianassidae) and Upogebia vasquezi (Upogebiidae) in an Amazon estuary, northern Brazil. Journal of the Marine Biological Association of the United Kingdom 92 (2): 295-303. doi:10.1017/ S002531541100097X.

Oliveira, D.B.; D.C. Silva \& J.M. Martinelli. 2012b. Description of early larval stages of Upogebia vasquezi (Gebiidea: Upogebiidae) reared in laboratory. Journal of the Marine Biological Association of the United Kingdom 92 (2): 335 342. doi:10.1017/S0025315411000956.

Posey, M.H. 1986. Predation on burrowing shrimp, distribution and community consequences. Journal of Experimental Marine Biology and Ecology 103 (1-3): 143-162. doi: 10.1016/0022-0981(86)90138-3.
Rodrigues, S.A. \& P.R. Pezzuto. 1999. Infraordem Thalassinidea (corruptos), p. 328-335. In: L. BucKup; G. Bond-Buckup (Eds). Os crustáceos do Rio Grande do Sul. Porto Alegre, UFRGS, 503p.

Ruppert, E.E.; R.S. Fox \& R.D. Barnes. 2005. Zoologia dos Invertebrados: uma abordagem funcional - evolutiva. Rio de Janeiro, Roca, 1145p.

SouzA, J.R.B. \& C.A.A. Borzone. 2003. A extração de corrupto, Callichiurus major (Say) (Crustacea, Thalassinidea), para uso como isca em praias do litoral do Paraná: as populações exploradas. Revista Brasileira de Zoologia 20 (4): 625-630. doi: 10.1590/S0101-81752003000400011.

Statsoft. 2004. Statistica (data analysis software system). Statsoft Inc., version 7. Available online at: www.statsoft.com [Acessed: 01/XII/2007].

Thatje, S. 2000. Notiax santarita, a new species of the Callianassidae (Decapoda, Thalassinidea) from the beagle channel, southernmost America. Crustaceana 73 (3): 289 299. doi: $10.1163 / 156854000504381$.

TeixeIra, R.L. \& H.S. Ś́. 1998. Abundância de macrocrustáceos decápodas nas áreas rasas do complexo lagunar Mundaú/ Manguaba, AL. Revista Brasileira de Biologia 58 (3): 393 404. doi: 10.1590/S0034-71081998000300005.

Villee, C.A.; W.F. Walker Jr. \& R.D. Barnes. 1984. Zoologia Geral. Rio de Janeiro, Guanabara, 683p.

Submitted: 08.III.2012; Accepted: 14.IV.2012.

Editorial responsibility: Paulo da Cunha Lana 


\section{Errata for ZOOLOGIA volume 29(2), page 150}

The correct version for Figures 19-20 is presented below:
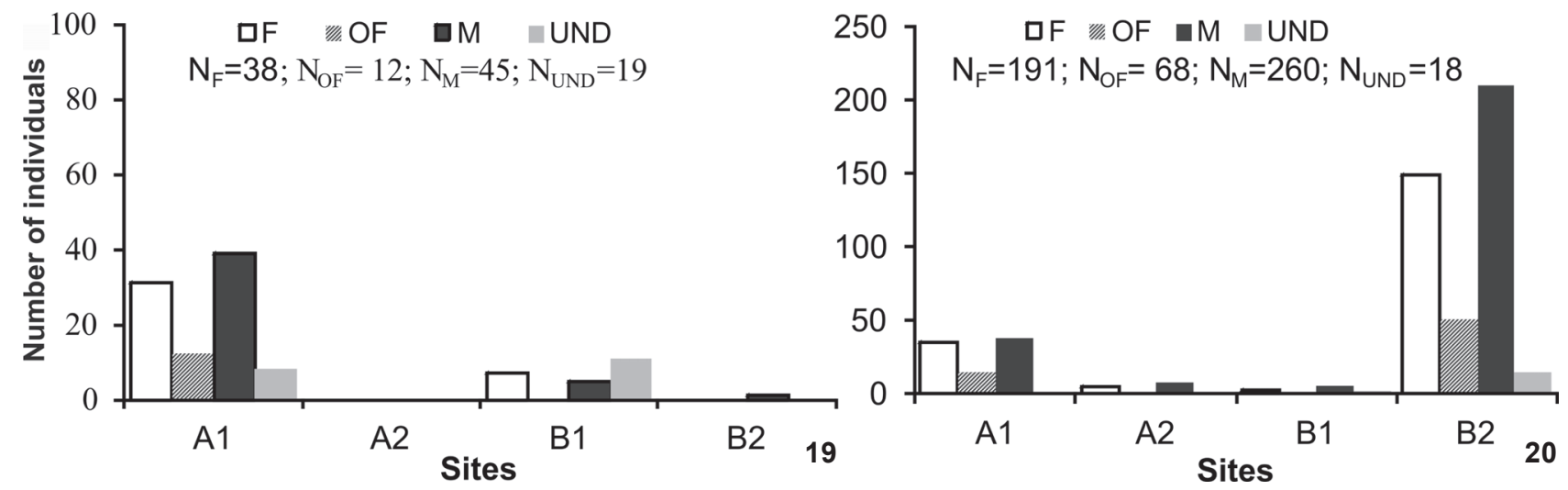

Figures 19-20. Number of $L$. siriboia and U. vasquezi individuals sorted by sex, according to species and sampling site from August 2006 to July 2007 in the Marapanim estuary, Pará, Brazil. (F) Female, (OF) ovigerous female, (M) male, (UND) undetermined sex. 